\title{
Implementasi Kebijakan Program Komando Strategis Pembangunan Pertanian (Kostratani) di Kecamatan Sukodono Kabupaten Sidoarjo
}

\section{Implementation of Policy for the Strategic Agricultural Development Command Program (Kostratani) in Sukodono District, Sidoarjo Regency}

\author{
Dyas Syahlia Izmi, Mahmudalia Rosa Yulaicho \& Ertien Rining Nawangsari* \\ Program Studi Administrasi Publik, Fakultas Ilmu Sosial dan Ilmu Politik, Universitas \\ Pembangunan Nasional "Veteran" Jawa Timur, Indonesia
}

Diterima: 20 Mei 2021 Direview: 20 Mei 2021; Disetujui: 06 Agustus 2021

*Coresponding Email: ertien_rining.adneg@upnjatim.ac.id

\section{Abstrak}

Program Komando Strategis Pembangunan Pertanian (Kostratani) muncul sebagai upaya pemerintah dalam mewujudkan kedaulatan pangan nasional. Kabupaten Sidoarjo yang memiliki luas daerah 71,424.3 km2 dan luas sawah 23,566 Ha, dengan sektor pertanian menjadi komoditas unggulan, berupaya mewujudkan tujuan program tersebut melalui Balai Penyuluhan Pertanian (BPP) Kecamatan, salah satunya di Sukodono. Tujuan dari penelitian ini ialah, mengetahui sejauh mana implementasi Program Komando Strategis Pembangunan Pertanian (Kostratani) di Kecamatan Sukodono Kabupaten Sidoarjo. Metode yang digunakan dalam penelitian ini ialah metode kualitatif deskriptif dengan teknik pengumpulan data melalui wawancara dengan pihak terkait serta observasi data. Teori yang digunakan merupakan teori Implementasi kebijakan dari Merilee S. Grindle. Hasil dari penelitian ini diharapkan dapat memberikan pengetahuan administrasi pubik terkait bidang pertanian khususnya Program Komando Strategis Pembangunan Pertanian (Kostratani). Selain itu, diharapkan dengan adanya penelitian ini dapat membantu para petani untuk lebih meningkatkan potensi pertanian serta urgensi dari kemajuan bidang pertanian dalam mendukung terwujudnya kedaulatan pangan nasional. Kata kunci: Implementasi Kebijakan; Program Kostratani; Pertanian; Kedaulatan Pangan Nasional.

\begin{abstract}
The Agricultural Development Strategic Command Program (Kostratani) emerged as the government's effort to realize national food sovereignty. Sidoarjo Regency, which has an area of 71,424.3 $\mathrm{km} 2$ and an area of 23,566 hectares of rice fields, with the agricultural sector being a leading commodity, seeks to realize the objectives of the program through the District Agricultural Extension Center (BPP), one of which is in Sukodono. The purpose of this study is to determine the extent of the implementation of the Strategic Agricultural Development Command Program (Kostratani) in Sukodono District, Sidoarjo Regency. This research uses descriptive qualitative research methods with data collection techniques through interviews with related parties and data observation. The theory used in this study is the theory of policy implementation from Merilee S.Grindle. The results of this study are expected to provide knowledge of public administration related to agriculture, especially the Strategic Agricultural Development Command Program (Kostratani). In addition, it is hoped that this research can help farmers to further increase agricultural potential and the urgency of agricultural progress in supporting the realization of national food sovereignty.
\end{abstract}

Keywords: Policy Implementation; Kostratani Program; Agriculture; National Food Sovereignty.

How to Cite: Izmi, D.S., Yulaicho, M.R., Nawangsari, E.R., (2021). Implementasi Kebijakan Program Komando Strategis Pembangunan Pertanian (Kostratani) di Kecamatan Sukodono Kabupaten Sidoarjo. Journal of Education, Humaniora and Social Sciences (JEHSS). 4 (2): 702-710. 


\section{PENDAHULUAN}

Pembangunan pertanian merupakan sebuah upaya pemerintah yang bertujuan untuk memenuhi kebutuhan dan ketersediaan pangan nasional, meningkatkan kesejahteraan petani, dan meningkatkan pendapatan nasional melalui ekspor produk pertanian. Pertanian pada kawasan perkotaan penting dilakukan untuk meningkatkan ketahanan pangan daerah maupun nasional. Pertanian di perkotaan merupakan kegiatan pertumbuhan, pengolahan, dan distribusi pangan serta produk lainnya melalui budidaya tanaman dan peternakan yang intensif di perkotaan dan daerah sekitarnya, dan menggunakan (kembali) sumber daya alam dan limbah perkotaan, untuk memperoleh keragaman hasil panen dan hewan ternak (Lanya et al., 2019). Sedangkan menurut Hanani, dalam (Maharisi et al., 2014) pertanian kota (Urban agriculture) didefinisikan sebagai usahatani, pengolahan, dan ditribusi dari berbagai komoditas pangan, termasuk sayuran dan peternakan di dalam atau pinggir kota di daerah perkotaan. Proses untuk mencapai ketahanan pangan tidak terlepas dari peran penyuluh sebagai tenaga teknis edukatif dan pemberdayaan petani (Wahyuni et al., 2019). Melalui Peraturan Menteri Pertanian Nomor 49 Tahun 2019 tentang Komando Strategis Pembangunan Pertanian, pemerintah pusat berupaya untuk mewujudkan kedaulatan pangan nasional melalui program tersebut.

Komando strategis pembangunan petani yang selanjutnya disebut Kostratani ialah proses pembaharuan serta pembangunan pertanian di kawasan kecamatan, melalui pengoptimalisasian tugas, fungsi dan peran Balai Penyuluhan Pertanian (BPP) dalam upaya mewujudkan keberhasilan pembangunan pertanian. Penyuluh pertanian merupakan sarana kebijakan yang dapat digunakan pemerintah untuk mendorong pembangunan pertanian (Ali et al., 2018). Komando Strategis Pembangunan Nasional merupakan suatu wujud gerakan pembangunan pertanian di Indonesia yang menyelaraskan kemajuan era industrialisasi 4.0. Keberlanjutan ketahanan pangan dipengaruhi oleh kapasitas petani dan inovasi teknologi (Saleh \& Suherman, 2021). Sehingga, program Kostratani ini sebagai bentuk perencanaan pembangunan sektor pertanian oleh pemerintah sebagai upaya peningkatan ketahanan pangan nasional melalui daerah. Seperti yang dikatakan oleh Sujono, kutipan (Winarsih et al., 2020) bahwa dengan kelembagaan penyuluhan yang kuat di daerah, dukungan pengawalan dan sinergi program-program pembangunan pertanian oleh pemerintah, swasta, dan masyarakat dapat terlaksana dengan baik.

Komando Strategis Pembangunan Pertanian atau Kostratani, memiliki 5 peran penting dalam pembanguan pertanian di Indonesia, yaitu sebagai pusat data dan informasi, pusat gerakan pembangunan pertanian, pusat pembelajaran, dan pusat konsultasi agribisnis, serta pusat pengembangan jejaring dan kemitraan. Upaya yang dilakukan pemerintah melalui Kostratani dalam pembangunan kedaulatan pangan, selaras dalam (Herawati, 2017) bahwa didalam UndangUndang No.19 tahun 2013 tentang perlindungan dan pemberdayaan petani menyebutkan bahwa untuk mewujudkan masyarakat adil dan makmur serta memenuhi hak dan kebutuhan dasar warga negara, Negara menyelenggarakan perlindungan dan pemberdayaan masyarakat, khususnya petani secara terencana, terarah dan berkelanjutan. Berdasarkan kutipan (Aryawiguna, 2021) menyebutkan Program Kostratani bertujuan untuk menghidupkan kembali dan memperkuat peran serta kapasitas aparat Kecamatan Balai Penyuluhan Pertanian, kemudian membuat kecamatan sebagai fokus pengendalian dan operasional rasional pertanian pengembangan.

Balai Penyuluhan Pertanian (BPP) merupakan lembaga penyuluhan pemerintah yang mempunyai tugas dan fungsi penyuluhan pertanian pada tingkat kecamatan serta merupakan unit kerja nonstruktural dengan wilayah kerja satu atau beberapa kecamatan. BPP mempunyai peran strategis yang harus mampu mengkoordinasikan, mensinergikan dan menyelaraskan kegiatan pembangunan pertanian pada Wilayah Kerja Penyuluhan Pertanian di Kecamatan dengan pihak terkait lainnya. Disebutkan oleh (Budi et al., 2018) bahwa tantangan yang dihadapi oleh pemerintah dalam penyuluhan pertanian ialah memenuhi kebutuhan untuk menyediakan makanan untuk negara, meningkatkan pendapatan pedesaan dan mengurangi kemiskinan, serta mengelola sumber daya alam secara berkelanjutan. Sebagai rumah penyuluh dan petani, BPP menjalankan fungsi sebagai Pusat Koordinasi dan Sinkronisasi program dan kegiatan pembangunan pertanian; Pusat Data dan Informasi Pertanian; Pusat Pembelajaran; Pusat 
Konsultasi Agribisnis; dan Pusat Pengembangan Kemitraan Usahatani dan koordinasi program pembangunan di kecamatan. Menurut Samsudin, dalam (Sudarmansyah, Ruswendi, Andi Ishak, Emlan Fauzi \& Firison, 2021), peran penyuluh pertanian sebagai fasilitator, motivator dan sebagai pendukung program kebijakan pemerintah serta merupakan titik sentral dalam memberikan penyuluhan kepada petani. Selain itu, peran penyuluh pertanian dalam perkembangan kelompok tani adalah segala sesuatu yang dapat dikembangkan untuk meningkatkan kemampuan kelompok tani, sehingga kelompok tani tersebut dapat bertahan atau berkembang mencapai tujuannya secara efektif (Ismail, 2020). BPP juga harus mampu mengawal program pembangunan di Kecamatan, yang salah satunya adalah Program Komando Strategis Pembangunan Pertanian.

Berdasarkan latar belakang tersebut, pemerintah berupaya mengatasinya dengan Program Kostratani yang diharapkan dapat mewujudkan pertanian Indonesia yang lebih baik. Melalui artikel ini dapat dilihat bagaimana implementasi dari program tersebut di salah satu kecamatan di Kabupaten Sidoarjo yaitu Kecamatan Sukodono. Dalam (Hertati \& Arif, 2018) dijelaskan bahwa Implementasi mencakup berbagai tindakan dan upaya yang dilakukan dengan tepat serta sesuai dengan rencana yang ditetapkan bersama, baik dalam instansi pemerintah, swasta maupun dalam instansi lainnya. Implementasi kebijakan publik memiliki tingkat analisis dengan model yang berbeda-beda. Semakin kompleks permasalahan kebijakan dan semakin mendalam analisis yang dilakukan, semakin diperlukan teori atau model yang relative operasional, yakni model yang mampu menjelaskan hubungan kausalitas antar variabel yang menjadi fokus analisis. (Abdoellah, 2016).

Menurut Merilee S. Grindle dalam (Subarsono, 2005), keberhasilan implementasi dipengaruhi oleh dua variabel, yaitu isi kebijakan (content of policy) dan lingkungan implementasi (context of implementation). Variabel isi dari kebijakan mengenai: 1) Kepentingan yang mempengaruhi. Kepentingan yang mempengaruhi kebijakan menyangkut sejauh mana kepentingan kelompok sasaran ada dalam isi kebijakan. Kepentingan tersebut berhubungan dengan berbagai kepentingan yang mempengaruhi suatu implementasi kebijakan; 2) Tipe manfaat, adalah jenis manfaat yang diterima oleh kelompok sasaran. Dalam esensi kebijakan, manfaat suatu kebijakan berupaya untuk menjelaskan bahwa di dalam suatu kebijakan harus terdapat jenis manfaat yang memberikan dampak positif terhadap pengimplementasian kebijakan yang akan dilaksanakan; 3) Derajat perubahan yang ingin dicapai, menunjukkan seberapa besar perubahan yang ingin dicapai melalui adanya suatu implementasi kebijakan; 4) Letak pengambilan keputusan. Pengambilan suatu keputusan di dalam suatu kebijakan memiliki peranan penting dalam pelaksanaan suatu kebijakan, pada variabel ini harus dijelaskan dimana letak pegambilan keputusan dari suatu kebijakan yang akan diimplementasikan; 4) Pelaksanaan program. Dalam melaksanakan suatu kebijakan harus didukung dengan adanya pelaksana kebijakan yang memiliki kompetensi untuk keberhasilan suatu kebijakan; 5) Sumber daya yang digunakan, pelaksanaan suatu kebijakan juga harus didukung dengan sumberdaya yang memadai dengan tujuan agar pelaksanaannya dapat berjalan dengan baik.

Variabel lingkungan kebijakan meliputi: 1) Seberapa besar kekuasaan, kepentingan, dan strategi yang dimiliki oleh para aktor yang terlibat dalam implementasi kebijakan; 2) Karakteristik lembaga dan penguasa, lingkungan dimana suatu kebijakan tersebut dilaksanakan juga memiliki pengaruh terhadap keberhasilannya, sehingga karakteristik dari suatu lembaga akan turut mempengaruhi suatu kebijakan; 3) Tingkat kepatuhan dan daya tanggap (responsifitas) kelompok sasaran. Sejauhmanakah kepatuhan dan respon dari pelaksana dalam menanggapi suatu kebijakan.

Berdasarkan teori implementasi Merilee S. Grindle, menjadi dasar pemikiran yang digunakan dalam penelitian ini. Peneliti akan melihat penerapan kebijakan program yang ada melalui keberadaan program tersebut dan manfaat yang didapatkan pihak terkait.

Penelitian terdahulu, telah banyak melakukan analisis terhadap kebijakan-kebijakan di bidang pertanian. Akan tetapi belum ada yang membahas secara spesifik mengenai kebijakan program pemerintah terbaru yaitu Kostratani. Karena bidang pertanian adalah sebuah pondasi untuk kelangsungan kehidupan bangsa dan negara. Adapun beberapa penelitian terdahulu yang dapat dijadikan referensi yaitu Syahyuti (2014), pada penelitiannya yang berjudul Implementasi 
Kebijakan untuk Mengoptimalkan Peran Penyuluh Pertanian Swasta di indonesia, menunjukkan bahwa kondisi dan keterbatasan pemerintah, serta tekanan komersialisasi hasil pertanian ditambah dengan pola komunikasi yang semakin berkembang, menyebabkan kehadiran penyuluh swasta merupakan satu keniscayaan. Namun demikian, untuk mengoptimalkan peran penyuluh swasta, pemerintah perlu segera mengimplementasikan kebijakan yang telah diambil serta menyusun pengaturan sistem penyuluhan baru yang lebih jelas di lapangan untuk mengoptimalkan peran penyuluh pertanian swasta (Syahyuti, 2014).

Peneltiian Sudarmansyah dkk (2021), menunjukkan bahwa peran penyuluh dalam melakukan kegiatan Penyuluhan pada saat wabah pandemi Covid-19 yaitu peran penyuluh sebagai pendukung kebijakan program pemerintah, motivator bagi petani dan fasilitator dalam mendukung kegiatan usahatani. Secara khusus, peran penyuluh lebih banyak di arahkan pada upaya dalam rangka mempertahankan ketahanan pangan $(71.15 \%)$ terutama untuk komoditas padi yakni sebesar $54 \%$ dengan cara metode penyuluhan langsung menggunakan protokol covid 19 sebanyak 79 \% (Sudarmansyah, Ruswendi, Andi Ishak, Emlan Fauzi \& Firison, 2021).

Penelitian dalam tulisan ini mengambil posisi yang berbeda dalam beberapa masalah dengan penelitian sebelumnya, karena berfokus pada implementasi kebijakan program Komando Strategis Pembangunan Pertanian (Kostratani). Kelebihan penelitian ini diharapkan bisa memberikan kontribusi kepada penelitian terdahulu sebagai referensi dalam dunia akademik. Tujuan dari penelitian ini ialah, mengetahui sejauh mana implementasi Program Komando Strategis Pembangunan Pertanian (Kostratani) di Kecamatan Sukodono Kabupaten Sidoarjo berjalan. Selain itu, diharapkan dengan adanya penelitian ini dapat membantu para petani untuk lebih meningkatkan potensi pertanian serta urgensi dari kemajuan bidang pertanian dalam mendukung terwujudnya kedaulatan pangan nasional.

\section{METODE PENELITIAN}

Penelitian ini merupakan penelitian deskriptif kualitatif. Teori yang digunakan merupakan teori Implementasi kebijakan dari Merilee S. Grindle. Informan penelitian meliputi Koordinator BPP, Petugas BPP dan Kelompok Tani. Data penelitian diperoleh melalui teknik wawancara dan observasi. Teknik pengumpulan wawancara, mendasarkan diri pada laporan tentang diri sendiri atau self-report, atau setidak-tidaknya pada pengetahuan dan atau keyakinan pribadi (Sugiyono, 2017). Data dianalisis dengan menggunakan teori Merilee S. Grindle dalam implementasi kebijakan. Proses analisis meliputi, aspek tipe manfaat, derajat perubahan yang diinginkan, letak pengambilan keputusan, sumber daya yang digunakan dan tingkat kepatuhan dan daya tanggap (responsifitas) kelompok sasaran. Fokus penelitian ini untuk mengetahui implementasi kebijakan program komando strategis pembangunan pertanian (kostratani) di Kecamatan Sukodono Kabupaten Sidoarjo. Sedangkan lokus penelitian ini terdapat di Balai Penyuluhan Pertanian (BPP) Kecamatan Sukodono Kabupaten Sidoarjo.

\section{HASIL DAN PEMBAHASAN Tipe Manfaat}

Salah satu variabel keberhasilan implementasi kebijakan menurut Merilee S. Grindle adalah tipe manfaat, yaitu jenis manfaat yang diterima oleh kelompok sasaran. Dalam esensi kebijakan, manfaat suatu kebijakan berupaya untuk menjelaskan bahwa di dalam suatu kebijakan harus terdapat jenis manfaat yang memberikan dampak positif terhadap implementasi kebijakan yang akan dilaksanakan. Salah satu tujuan dari adanya implementasi kebijakan ketahanan pangan ialah penguatan kelembagaan pangan dan penguatan koordinasi ketahanan pangan melalui sinergi program dan pelibatan seluruh stakeholders dalam pembangunan pangan dan gizi serta dukungan kebijakan kementerian/ lembaga (Rahmi, 2020).

Berdasarkan hasil wawancara kepada Petugas BPP Kecamatan Sukodono, manfaat dari Program Kostratani ini adalah membuat petugas semakin "melek" data, yang artinya sebelum adanya program tersebut data pertanian kurang termanajemen dengan baik, setelah adanya Program Kostratani, mereka sebagai petugas dituntut untuk update data pertanian setiap hari, 
yang meliputi laporan harian tanam, panen, pendistribusian bantuan pupuk dan sebagainya. Laporan data tersebut akan diberikan kepada dinas pertanian tingkat kabupaten, kemudian menjadi laporan data administrasi pada tingkat nasional. Sehingga data BPP terkait laporan pertanian tersebut yang menjadi output adanya fungsi administrasi pemerintah daerah.

Selain itu, manfaat program Kostratani yang dapat dirasakan oleh Balai Penyuluhan Pertanian di Kecamatan Sukodono ialah meningkatnya perhatian dari pemerintah pusat terkait pemberian anggaran bantuan fasilitas. Meskipun, fasilitas tersebut belum terdistribusikan secara langsung, Pemerintah telah merencanakan anggaran khusus untuk BPP. Sedangkan dari sisi petani, teknologi yang semakin maju seperti mesin tanam dan panen, sebenarnya sangat membantu pekerjaan petani. Akan tetapi masih ditemui kendala-kendala yang menjadikan teknologi tersebut kurang dimanfaatkan. Dengan adanya program pemerintah di sektor pertanian khususnya Kostratani, para petani lebih sering melakukan konsultasi kepada BPP terkait hal-hal yang berhubungan dengan kondisi lapangan pertanian mereka, seperti pemilihan pupuk dan benih, pendaftaran AUTP (Asuransi Usaha Tani Padi), dan lain sebagainya. Disisi lain, petani merasa terbantu dengan adanya pupuk bersubsidi dan bantuan benih yang dikeluarkan oleh pemerintah, meskipun dalam realisasinya saat ini harga pupuk semakin mahal sedangkan barang semakin langka. Begitupun dengan bantuan benih dari pemerintah, para petani merasa terbantu, akan tetapi bantuan benih yang ada tidak sesuai dengan yang digaungkan.

\section{Derajat Perubahan Yang Ingin Dicapai}

Derajat perubahan melalui teori Grindle dapat dijadikan tolak ukur terhadap pencapaian dalam proses kegiatan program Kostratani. Berdasarkan rencana program Kostratani yang disusun oleh pemerintah pusat, strategi yang ingin dicapai berupa (i) Meningkatkan peran Pemimpin Daerah (Kepala desa, Camat, Bupati, dan Gubernur) untuk menggerakan penyuluh pertanian, petugas lapangan lainnya, petani dan pelaku usaha dalam pembangunan pertanian. (ii) Meningkatkan sinergitas pelaku dan program. (iii) Meningkatkan jejaring kerja Kostratani dengan instansi pemerintah lainnya dan swasta di daerah. (iv) Meningkatkan peran pemimpin non formal kemasyarakatan dalam pembangunan pertanian.

Melalui pencapaian strategi tersebut, upaya yang dilakukan oleh pemerintah melalui peran dari Kostratani yaitu sebagai pusat data dan informasi, pusat gerakan pembangunan pertanian, pusat pembelajaran, pusat konsultasi agribisnis, dan pusat pengembangan jejaring kemitraan. Informasi yang didapatkan melalui wawancara dengan Koordinator BPP Kecamatan Sukodono ialah implementasi yang sedang berlangsung saat ini ialah sekitar 25\% dari keseluruhan peran program Kostratani. Karena program Kostratani baru digencarkan pada tahun 2020 di Kabupaten Sidoarjo, hal tersebut terjadi karena Kabupaten sidoarjo tidak termasuk percontohan awal di tahun 2019. Baru pada percontohan kedua di 2020, Sidoarjo menerima program ini termasuk di Kecamatan Sukodono.

Implementasi yang sedang dilaksanakan adalah terkait data, sebelum adanya program Kostratani, data tidak di update setiap hari sedangkan saat ini Kementerian ingin dengan adanya Kostratani dapat memperoleh data yang lengkap dan terakses di Pusat setiap hari. Misalkan terkait hasil tanam, kementerian mengetahui komoditas yang sedang berlangsung melalui pelaporan utama perhari. Sedangkan untuk pupuk, Kementrian terdapat 2 (dua) aplikasi pelaporan yaitu RDKK dan E-Verval. RDKK ialah Rencana Definitif Kebutuhan Kelompok, sehingga rencana kebutuhan kelompok tahun yang akan datang telah disusun pada tahun ini. Kemudian untuk pupuk yang telah tersalur, dicatat melalui aplikasi E-Verval (Verifikasi dan Validasi). Selain perubahan diatas, terkait peran BPP sebagai pusat konsultasi agribisnis telah dijalankan sejak sebelum adanya program Kostratani tersebut. Setiap bulan, petugas melakukan pengecekan melalui kunjungan rumah untuk mengetahui perkembangan para petani dan sosialisasi jika terdapat program baru dari pemerintah.

Menurut petugas BPP lainnya, program Kostratani dalam peran sebagai pusat pengembangan pertanian masih belum dirasakan signifikan oleh para petani. Karena, program Kostratani dianggap masih baru sehingga tidak mempengaruhi jumlah hasil tani yang diperoleh petani. Adanya penggunaan teknologi mesin dalam proses penanaman juga telah dilakukan sejak 7060 http://mahesainstitute.web.id/ojs2/index.php/jehss 
sebelum adanya program Kostratani. Teknologi pertanian dapat berperan dalam meningkatkan produktivitas pangan, meningkatkan diversifikasi dalam jenis dan kualitas pangan, meningkatkan nilai tambah, kesempatan kerja, dan menjaga kelestarian sumberdaya alam dan lingkungan hidup, sehingga meningkatkan sistem ketahanan pangan (Prabowo, 2010). Para kelompok tani juga memiliki target keinginan yang ingin dicapai. Melalui hasil wawancara dengan kelompok tani Kecamatan Sukodono, para petani ingin perbaikan dalam bantuan subsidi pupuk dengan menambah jumlah pupuk kepada para petani.

\section{Letak Pengambilan Keputusan}

Menurut Merilee S. Grindle dalam (Subarsono, 2005) letak pengambilan keputusan akan menjelaskaan apakah letak sebuah program sudah tepat atau belum. Pengambilan sebuah keputusan di dalam sebuah kebijakan memegang peranan penting dalam pelaksanaan sebuah kebijakan. Sebuah kebijakan dibuat tentu karena adanya latar belakang yang mendorongnya. Item pertanyaan pada wawancara mengenai letak pengambilan keputusan ini adalah bagaimana ketepatan dari adanya tiap-tiap kebijakan program yang ada pada sektor pertanian, khususnya Kostratani. Perubahan yang ada disini dilihat dari perspektif petugas BPP dan petani mengenai adanya kebijakan yang ada, apakah keberadaannya sudah tepat ataukah belum. Dalam melaksanakan kebijakan, keberhasilannya harus didukung oleh seluruh stakeholder. Khususnya melalui partisipasi masyarakat untuk menjalankan serta ikut serta dalam kegiatan yang ada berdasarkan kebijakan yang telah dibuat. Partisipasi adalah keikutsertaan atau keterlibatan masyarakat dalam proses identifikasi masalah, pengambilan keputusan, pelaksanaan juga keterlibatan dalam evaluasi pengatasan masalah. (Aminah \& Prasetyo, 2018).

Menurut petugas BPP Kecamatan Sukodono, adanya Program Kostratani adalah suatu inovasi yang baik. Akan tetapi, hal tersebut masih dibarengi dengan kekurangan dalam pelaksanaannya. Pemerintah menggaungkan Program Kostratani dengan segala aturan dan mekanisme yang ada. Namun hingga saat ini, fasilitas pendukung atau sarana prasarana program belum tersedia. Seperti adanya ruang pertemuan, sound system, internet, dan lain sebagainya yang diperlukan untuk menunjang keberhasilan implementasi program.

Koordinator BPP Sukodono berpendapat, bahwa keberadaan kebijakan terkait Program Kostratani sudah tepat berada di Balai Penyuluhan Pertanian, karena susunan yang diperlukan dalam melakukan pembangunan pertanian juga tepat sasaran.

Jika dilihat dari sisi petani, para petani masih kurang mengerti dengan Program Kostratani, karena umur program yang masih tergolong baru dan terhambat penginformasiannya karena Pandemi Covid-19. Meskipun begitu, para petani tetap melakukan konsultasi pertanian kepada BPP yang merupakan salah satu tujuan dari Program Kostratani.

\section{Sumber Daya Yang Digunakan}

Sumber daya merupakan salah satu penilaian yang diukur dalam analisis implementasi kebijakan menurut teori Grindle. Sumber daya adalah sebuah nilai potensi yang dimiliki oleh suatu materi atau unsur tertentu dalam kehidupan. Sumber daya tidak selalu bersifat fisik, tetapi juga non-fisik. Sumber daya ada yang dapat berubah, baik menjadi semakin besar maupun hilang, dan ada pula sumber daya yang kekal. Selain itu, dikenal pula istilah sumber daya yang dapat pulih atau terbarukan (renewable resources) dan sumber daya tak terbarukan (non-renewable resources). Yang termasuk dalam sumber daya dapat pulih ialah tanaman dan hewan (sumber daya hayati).

Menurut petugas Balai Penyuluhan Pertanian (BPP) Kecamatan Sukodono, sumber daya yang digunakan dalam proses pelaksanaan program Kostratani terlebih pada sumber daya manusia masih kekurangan anggota untuk melakukan kegiatan administrasi, hal tersebut mengakibatkan pegawai di Balai Penyuluhan Pertanian menjadi merangkap dalam kegiatan input data. Hal tersebut sesuai dengan hasil wawancara Koordinator BPP Kecamatan Sukodono, bahwa saat ini Program Kostratani belum didukung dengan kemampuan sumber daya manusia yang 
tepat, karena adanya kekurangan pegawai khusus administrasi serta kurangnya pelatihan kepada para petani.

Berdasarkan rencana program Kostratani yang disusun oleh pemerintah pusat, salah satu sumber daya yang seharusnya menunjang kegiatan program ini ialah pengadaan bantuan prasarana oleh pemerintah pusat berupa komputer, drone, LCD, jaringan internet, serta renovasi. Fasilitas ataupun biaya yang direncanakan oleh pemerintah diharapkan akan memberikan keuntungan bagi keseluruhan. Namun, bantuan fasilitas tersebut belum seluruhnya terealisasikan di BPP Sukodono, bantuan yang telah diterima berupa komputer beserta jaringan internet.

Selain pendapat dari petugas Balai Penyuluhan Pertanian Kecamatan Sukodono, Para kelompok tani juga berpendapat mengenai sumber daya yang digunakan dalam proses kegiatan tani. Sumber daya yang dibutuhkan mulai dari bibit/benih unggul, subsidi pupuk, dan pengairan irigasi sawah. Untuk kebutuhan sumber daya tersebut, pemerintah telah memberikan bantuan benih/bibit unggul dan subsidi pupuk. Namun, didalam proses pelaksanaan program subsidi tersebut, kelompok tani berharap bahwa pemeritah dapat menambah jumlah pupuk berkualitas yang di peroleh para petani. Petani juga menginginkan adanya penyediaan alat-alat teknologi seperti alat tanam dan drone untuk menunjang hasil kinerja. Hal tersebut diharapkan dapat mendukung terciptanya komoditas pertanian yang unggul. Dalam (Dewi \& Santoso, 2014) beberapa faktor yang dapat mempengaruhi peningkatan komoditas unggulan ialah sumber daya manusia, teknologi dan juga bahan baku. Ketiganya menjadi kendala bagi kelompok tani yang seharusnya segera dibenahi oleh pemerintah. Pendapat atau persepsi ini menjadi proses dalam menemukan informasi melalui indera untuk memilih, mengatur, dan menafsirkan informasi yang diterima menjadi gambaran yang bermakna (Laiyinah et al., 2021). Pendapat dari petani maupun petugas BPP sebaiknya perlu dijadikan dasar untuk mencapai keberhasilan yang ingin dicapai dari program Kostratani.

\section{Tingkat Kepatuhan Dan Daya Tanggap (Responsifitas) Kelompok Sasaran}

Kepatuhan dan respon dari para pelaksana juga dirasa menjadi sebuah aspek penting dalam proses pelaksanaan suatu kebijakan, maka yang hendak dijelaskan pada poin ini adalah sejauhmanakah kepatuhan dan respon dari pelaksana dalam menanggapi suatu kebijakan.

Tanggapan dari Petugas Balai Penyuluhan Pertanian di Kecamatan Sukodono terhadap Program Kostratani yang diselenggarakan oleh Kementerian Pertanian adalah menyambut baik setiap program yang diberikan pemerintah. Sedangkan petani, sejauh ini belum ada respon seperti yang diharapkan, namun kepatuhan dan antusiasme petani terhadap program-program yang sudah ada sangat baik. Dalam program-program tersebut, tentu terdapat proses administratif yang harus dilengkapi oleh petani, sedangkan beberapa kondisi sumber daya manusianya tidak mampu karena faktor usia yang tidak muda lagi, jadi BPP mengambil peran untuk membantu proses input data, hal ini untuk memberikan data yang terbuka dan mudah untuk diakses. Karena tidak sedikit petani yang belum mengetahui Program Kostratani, maka Balai Penyuluhan Pertanian memiliki strategi untuk memperkenalkan program tersebut kepada para petani.

\section{SIMPULAN}

Sejak dikeluarkannya Peraturan Menteri Pertanian Nomor 49 Tahun 2019 tentang Komando Strategis Pembangunan Pertanian (Kostratani), program tersebut telah berjalan dengan baik dan tepat keberadaannya. Selama pelaksanaan program sejak 2020, setidaknya sudah $25 \%$ proses yang berjalan. Hal ini menunjukkan suatu progres yang baik untuk implementasi kebijakan tersebut, mengingat satu tahun kebelakang Indonesia sedang dilanda pandemi Covid-19. Meskipun terhambat karena Pandemi Covid-19, petugas BPP dan petani tetap merespon dengan baik serta tetap patuh terhadap aturan dan mekanisme yang telah ditetapkan. Akan tetapi, pelaksanaan Program Kostratani belum didukung dengan kemampuan sumber daya manusia yang tepat, karena adanya kekurangan pegawai khusus administrasi serta kurangnya pelatihan kepada para petani mengenai perkembangan dunia pertanian saat ini. Disisi lain, pelaksanaan program Kostratani di Kecamatan Sukodono belum didukung oleh fasilitas penunjang yang lengkap sesuai dengan yang tertulis dalam petunjuk teknis Program Komando Strategis Pembangunan Pertanian 
(Kostratani). Adapun saran yang penulis ajukan kepada pemerintah adalah pemenuhan fasilitas penunjang untuk Balai Penyuluhan Pertanian (BPP) selaku pelaksana program, ketersediaan pupuk bagi petani tidak lagi langka dan harga pupuk bisa stabil bahkan murah, adanya bantuan berupa teknologi pertanian seperti mesin tanam, mesin panen, dan drone, untuk kegiatan pertanian yang semakin baik kedepannya, mengingat bahwa pertanian adalah garda terdepan dalam ketahanan pangan nasional.

\section{UCAPAN TERIMAKASIH}

Ucapan terima kasih kami sampaikan kepada seluruh pihak yang mendukung pelaksanaan dan penulisan penelitian ini, antara lain keluarga, pembimbing, serta Balai Penyuluhan Pertanian Kecamatan Sukodono Kabupaten Sidoarjo, kelompok tani "Tani Makmur II" dan kelompok tani yang terdapat di Desa Kloposepuluh Kecamatan Sukodono sebagai sumber data utama penelitian ini.

\section{DAFTAR PUSTAKA}

Abdoellah, A. (2016). Buku - Teori Dan Analisis Kebijakan Publik.pdf. Alfabeta CV.

Ali, H., Tolinggi, W., \& Saleh, Y. (2018). Persepsi Petani terhadap Kinerja Penyuluh Pertanian lapangan di Desa Talumelito Kecamatan Telaga Biru Kabupaten Gorontalo. Agrinesia, 2(2), 111-120.

Aminah, S., \& Prasetyo, I. (2018). Partisipasi masyarakat dalam pengembangan organisasi wahana kesejahteraan sosial berbasis masyarakat (WKSBM). JPPM (Jurnal Pendidikan Dan Pemberdayaan Masyarakat), 5(1), 61-73. https://doi.org/10.21831/jppm.v5i1.17531

Aryawiguna, M. U. H. I. (2021). An Extension of Competence and Technology in Supporting the Effectiveness of Kostra Tani 's Program on Agricultural Products. 6(4).

Budi, S., Muhammad, A., Yusuf, H., \& Ali, M.M. (2018). Penyuluhan Pertanian : Teori dan Penerapannya. CV. Sefa Bumi Persada.

Dewi, K. A. N. P., \& Santoso, E. B. (2014). Pengembangan Komoditas Unggulan Sektor Pertanian Tanaman Pangan di Kabupaten Karangasem Melalui Pendekatan Agribisnis. Jurnal Teknik Pomits, 3(2), 1-6.

Herawati, I. E. (2017). Strategi Pemberdayaan Kelompok Tani Sistem Hutan Kerakyatan (Shk) Lestari Kawasan Taman Hutan Raya Wan Abdurrahman-Hurun Kabupaten Pesawanan Lampung. Jurnal Agribisnis Terpadu, 10(1), 26. https://doi.org/10.33512/jat.v10i1.5051

Hertati, D., \& Arif, L. (2018). Implementasi Kebijakan Pengelolaan Dana Desa di Desa Pejambon Kabupaten Bojonegoro Jawa Timur. Journal of Economics, Business, and Government Challenges, 1(1), 40-49. https://doi.org/10.33005/ebgc.v1i1.8

Ismail, L. (2020). Peran Penyuluh Pertanian dalam Perkembangan Kelompok Tani Di Balai Penyuluhan Pertanian Perikanan dan Kehutanan (BP3K) Kabupaten Bogor. 1(2), 74-91.

Laiyinah, F. N., Ningsih, G. M., \& Amir, N. O. (2021). Farmers' Perception of Among Tani Application. SOCA: Jurnal Sosial Ekonomi Pertanian, 15(1), 19-29.

Lanya, I., Trigunasih, N. M., Sunarta, A. N., \& Arthagama, I. D. made. (2019). Pemberdayaan Kelompok Dasa Wisma Agropertiwi Dalam Pengembangan Pertanian Perkotaan Di Dusun Permata Anyar Desa Ubung Kaja Kecamatan Denpasar Utara Kota Denpasar. Buletin Udayana Mengabdi, 18(4), 53-57. https://doi.org/10.24843/bum.2019.v18.i04.p10

Maharisi, S., Machfud, \& Maulana, A. (2014). Manajemen Strategi Pengembangan Pertanian Kota (Urban Agriculture) di Kota Tangerang Selatan. Jurnal Aplikasi Manejemen (JAM), 12(3), 351-361.

Prabowo, R. (2010). Kebijakan Pemerintah Dalam Mewujudkan Ketahanan Pangan Di Indonesia Rossi Prabowo Staf Pengajar Fakultas Pertanian Universitas Wahid Hasyim Semarang. 6(2), 62-73.

Rahmi, H. (2020). Implementasi Kebijakan Ketahanan Pangan Dalam Meningkatkan Kesejahteraan Masyarakat Di Kabupaten Pesisir Selatan (Studi Kasus Pengelolaan Cadangan Pangan Masyarakat). 2(1), 12-23.

Saleh, K., \& Suherman, S. (2021). Model Kapasitas Petani Padi Sawah dalam Mendukung Ketahanan Pangan Berkelanjutan di Kabupaten Tangerang. Jurnal Penyuluhan, 17(1), 40-51. https://doi.org/10.25015/17202132887

Subarsono, A. (2005). Analisis Kebijakan Publik Konsep, Teori dan Aplikasi. Pustaka Pelajar.

Sudarmansyah, Ruswendi, Andi Ishak, Emlan Fauzi, S. Y. dan, \& Firison, J. (2021). Peran Penyuluh Pertanian Dalam Mendukung Ketahanan Pangan Pada Saat Wabah Pandemi Covid-19. Jurnal EMBA, 14(1), $1598-1612$.

Sugiyono. (2017). Metode Penelitian Administrasi. Alfabeta CV. 
Syahyuti. (2014). Implementasi Kebijakan Untuk Mengoptimalkan Peran Penyuluh Pertanian Swasta di Indonesia. Analisis Kebijakan Pertanian, 12(1), 19-34.

Wahyuni, S., Helmi, H., Tnjung, H. B., \& Oktavia, Y. (2019). Peran Balai Penyuluhan Pertanian (Bpp) Dalam Penyuluhan Komoditi Pangan (Studi Kasus Di Kabupaten Tanah Datar). Agrisep, 18(2), 235-248. https://doi.org/10.31186/jagrisep.18.2.235-248

Winarsih, A., Djaka Mastuti, \& Detia Tri Yunandar. (2020). Peningkatan Kinerja melalui Program Kostratani di Balai Penyuluhan Pertanian (BPP) Prafi, Kabupaten Manokwari. Jurnal Triton, 11(2), 58-67. https://doi.org/10.47687/jt.v11i2.151 